\title{
Assessment of Progress Towards 20-20-20 Targets: Evidence from Baltic States
}

Dalia Streimikiene

\begin{abstract}
The 2020 climate and energy package adopted in 2009 sets three key targets for EU Member States: $20 \%$ cut in greenhouse gas emissions (from 1990 levels); to ensure $20 \%$ of renewables in final energy consumption and to achieve 20\% improvement in energy efficiency from 2005 levels. The paper analyses the progress of selected countries in achieving climate and energy targets by 2020 . Baltic States, namely Lithuania, Latvia, and Estonia were selected for comparative assessment of their achievements in GHG emission reduction, energy efficiency improvement and use of renewable energy sources. Indicator's framework was constructed to capture the most important drivers of GHG emission reduction from fuel combustion. These indicators allow to compare countries in their achievements by assessing their main energy and climate change policies. The analysis and comparison of the trends of the main indicators allows to define the best performing country and the reason of this. Policy implications were developed for Baltic States to pursue further progress in achieving energy and climate targets for 2030 and 2050.
\end{abstract}

KEY WORDS: $\quad$ Renewable energy, energy efficiency, greenhouse gas emissions, energy and climate targets, policies, Baltic States.

JEL Classification: H30, P18, Q20, Q30.

Mykolas Romeris University, Faculty of Public Governance and Business, Vilnius, Lithuania

\section{Introduction}

The climate and energy package aims to guarantee that European Union (EU) implements its climate and energy targets for 2020 acknowledged as the 20-20-20 targets. It establishes 3 related targets for EU Member States (MS) by 2020: 20\% increase in the EU's energy efficiency comparing to year 2005 levels; increasing the portion of renewable energy sources to $20 \%$ in final energy and Greenhouse Gas Emission (GHG) emission reduction by $20 \%$ in comparison with year 1990 level.

Achieving the targets of the 2020 climate and energy package should provide for additional benefits, like improvement of energy supply security due to reduced dependency on imported energy

Correspondence concerning this article should be addressed to: Dalia Streimikiene, Mykolas Romeris University, Faculty of Public Governance and Business, Vilnius, Lithuania. E-mail: dalia@mail.lei.lt and creation of new jobs, advancing green growth and making European Union more competitive.

Though in 2020, the EU was experiencing almost $10 \%$ economic downturn due to Covid-pandemics, the 20-20-20 goals set for 2020 were met almost by all EU MS. The covid 19 health crisis is continuing in 2022 as well and having negative impacts on economic development and energy sector as well. Due to a sharp decrease in air and road transport activities, the energy demand and supply was falling in EU. At the same time GHG emission were declining.

However, with recovery of economy after Covid-19 health crisis, energy demand and supply are expected to increase and the approaching of low carbon energy transitions for the period 2030 to 2050 requires attention of policy makers. The new policies might be necessary to follow low carbon transition however for policy formulation 
the results of countries in approaching to the 2020-20 targets need to be analysed and compared by identifying the main drivers and obstacles of GHG emission reduction.

In order to achieve the 20-20-20 targets EU MS, have to increase energy efficiency in all final sector as well in energy generation sector, to ensure fast penetration of renewables in primary sector like electricity and heat generation as well in transport. Though there are plenty of papers analyzing progress and achievement of EU MS in low carbon transition ( $\mathrm{Lu}$ et al., 2020; Yan et al., 2020a, 2020b; Yu et al., 2020; Batinge et al., 2019; Brodny \& Tutak, 2020; Gralla et al., 2017; Singh et al., 2019) there is the lack of studies providing tested comprehensive indicator frameworks to perform comparative assessment of EU MS based on analysis of the main 20-0-20 indicators and their drivers (supplement indicators).

This paper aims to overcome this gap. In this paper, indicator framework was developed to analyze progress of EU MS in implementing 20-20-20 targets. The three-country case was developed by applying this indicator framework which represents an interesting and valuable example of comparative assessment of countries results achieved in implementing GHG emission reduction, renewable energy and energy efficiency targets and allows to generate pertinent policy implications and recommendations for decision makers.

\section{Literature Review}

There are many possible approaches to energy transitions and creation of carbon neutral society, as policies to phase out fossil fuels and switch to $100 \%$ of renewables by 2050. In the end of 2019, EU MS agreed to follow climate neutrality goal by 2050 (Liobikiene \& Butkus, 2017).

Energy efficiency and use of renewables are the most important measures to reduce greenhouse gas emissions (Al-Marri et al., 2018; Clausen \& Rudolph, 2020). Therefore, climate and energy targets 20-20-20 are interrelated (Tagliapietra et al., 2019).

Energy efficiency improvements can provide for GHG emission reduction without any costs and this is the most efficient way to deal with climate change caused by energy generation and consumption. For achieving energy intensity of Gros Domestic Product (GDP) reduction by $20 \%$, EU MS have to implement energy efficiency improvement measures in all final sectors like industry, service, transport, agriculture and especially residential sector which is the main energy consumer in EU. Energy efficiency is often described as being a win-win solution as by saving energy, it is possible to save customers money. Energy efficiency improvement in energy generation sector is also very important and renewable energy generation technologies also delivering to the increase of efficiency of fuel combustion (Dell' Anna, 2020).

The main measures to promote energy efficiency are: (a) minimum energy performance requirements for buildings; energy performance certificates; (b) Inspection schemes for heating and air-conditioning, implementation of nearly zero-energy buildings; (c) financial instruments; (d) energy performance contracting etc.

Renewable energy sources (RES) like wind, solar, hydrothermal, geothermal, biomass, biofuel and hydropower etc. can significantly contribute to GHG emission reduction however switching to renewables has high upfront costs which need financial support. Renewable energy provides many benefits in terms of energy supply security, improvement in energy efficiency, and environmental impact reduction, creation of new jobs and boosting economies (Gielen et al., 2019; Nathaniel \& Khan, 2020). Therefore, external benefits of RES are still not integrated and these energy generation technologies requires policies and measures to address and integrate these benefits (Aklin et al., 2018; Elavarasan et al., 2020).

There are other important barriers of penetration of renewables necessary to overcome by policies and measures. These barriers can be grouped as economic, institutional, political and legislative and behavioral linked to lack of awareness. The social and environmental barriers are linked to the lack of experience with regulations (Lu et al., 2020; Neofytou et al., 2020).

In order to overcome all these barriers policies and measures are necessary. These policies include: price and quantity setting policies, dictating prices or quantities; investment cost decrease policies, providing incentives for investors as lower investment costs; public investments and market facilitation actions, offering a broad range of policies overcoming market barriers and facilitating development of renewable energy markets (Aslanturk \& Kiprizli, 2020; Bergek \& Mignon, 2017). 


\section{Data and Methods}

The main data for comparative assessment of selected countries (Baltic States) will be collected based on indicator framework provided in Table 1. All selected indicators are reported for EU MS in Eurostat and allows to develop comparative assessment of countries. The newest data available in Eurostat is for 2019. Therefore, in tracking progress the data from 2010 to 2019 was collected.
The framework of indicators consists of three areas: energy efficiency, renewables, and GHG emission reduction. The description of indicators and its relevance are also addressed in Table 1. The highlighted indicators in Bold font are the main indicators (primary energy intensity, share of renewables in final energy consumption, and GHG emission reduction) are set as the targets in climate and energy packages and policy documents.

\section{Table 1}

Indicator Framework for Monitoring Progress Towards EU Climate and Energy Targets 20-20-20

Main indicators

\begin{tabular}{|c|c|}
\hline Main indicators & Description \\
\hline \multicolumn{2}{|r|}{ Energy efficiency } \\
\hline $\begin{array}{l}\text { Primary energy intensity, toe/Million EUR } \\
2010 \text { prices }\end{array}$ & Primary energy intensity is the primary energy consumption per unit of GDP \\
\hline $\begin{array}{l}\text { Final energy consumption per capita, toe/thou- } \\
\text { sand inhabitants }\end{array}$ & $\begin{array}{l}\text { The ratio between final energy consumption in households' sector and the population } \\
\text { of the country }\end{array}$ \\
\hline EUR 2010 prices & The final energy consumed in the industry sector. \\
\hline $\begin{array}{l}\text { Final energy consumption per square meter in } \\
\text { residential sector, climate corrected, kgoe } / \mathrm{m} 2\end{array}$ & $\begin{array}{l}\text { The ratio between final energy consumption per dwelling and the average size of dwell- } \\
\text { ings (floor area). Climate corrected mean that it is assessed for the energy consumption } \\
\text { used for heating only and by the use of heating }\end{array}$ \\
\hline $\begin{array}{l}\text { Proportion of collective transport in all passen- } \\
\text { gers' transport, \% }\end{array}$ & $\begin{array}{l}\text { The share of collective land transport (i.e., trains, motor coaches, buses and trolley } \\
\text { buses) in all passengers' transport means. }\end{array}$ \\
\hline $\begin{array}{l}\text { Final energy intensity in services sector, toe/ } \\
\text { Million EUR } 2010 \text { prices }\end{array}$ & $\begin{array}{l}\text { The ratio between final energy consumption in commercial and public services sector } \\
\text { and gross value added for services related sectors. }\end{array}$ \\
\hline \multicolumn{2}{|r|}{ Renewable energy sources } \\
\hline $\begin{array}{l}\text { Renewable energy share in final energy con- } \\
\text { sumption, \% }\end{array}$ & The share of renewables in final energy consumption \\
\hline RES share in transport, \% & The share of renewables in fuel consumption in transport sector \\
\hline RES share electricity, \% & The share renewable energy in electricity generation \\
\hline RES share heating \& cooling, \% & The share renewable energy in heating and cooling generation \\
\hline $\begin{array}{l}\text { Fossil fuels avoidance by RES, \% vs } 2005 \\
(2005=0.0 \%)\end{array}$ & $\begin{array}{l}\text { Indicator calculated by assuming that the increase of RES since } 2005 \text { has substituted } \\
\text { an equivalent size of energy that would have been supplied by other fossil fuel sources. }\end{array}$ \\
\hline \multicolumn{2}{|r|}{ GHG emissions } \\
\hline $\begin{array}{l}\text { 1. GHG emissions reductions (base year }=1990 \text { ), } \\
\%\end{array}$ & $\begin{array}{l}\text { The total greenhouse gas emissions (without LULUCF, with international aviation) as } \\
\text { declared by countries to UNFCCC }\end{array}$ \\
\hline $\begin{array}{l}\text { GHG intensity, t CO2eq / Million EUR } 2010 \\
\text { prices }\end{array}$ & $\begin{array}{l}\text { Total GHG emissions (with international aviation, without LULUCF) relative to Gross } \\
\text { Domestic Product in chain linked volumes } 2015 \text { (GDP 2015) }\end{array}$ \\
\hline GHG per capita, kg CO2-eq/inhabitant & $\begin{array}{l}\text { The GHG level per capita is the ratio of the total GHG emissions (with international } \\
\text { aviation, without LULUCF) in the country to total population. }\end{array}$ \\
\hline $\begin{array}{l}\text { GHG intensity of power \& heat generation, } \\
\mathrm{CO} 2 / \text { toe }\end{array}$ & $\begin{array}{l}\text { The ratio between GHG from public electricity and heat production and the total gross } \\
\text { electricity production and total gross derived heat production. }\end{array}$ \\
\hline GHG emissions avoided due to RES, \% vs 2005 & The estimated GHG emissions avoided due to renewables are represented as share of total \\
\hline$(2005=0.0 \%)$ & GHG emissions (with international aviation, without LULUCF). \\
\hline
\end{tabular}


All indicators consisting in the developed framework are very important for tracking progress of countries towards climate and energy targets in 2020 as all selected indicators provide important information for understanding the main drivers of progress in implementing energy efficiency, renewables and GHG emission reduction. In the following section the trends of these indicators will be analyzed and the ranking of countries (Baltic States) according to progress achieved in 2019 will be provided.

\section{Discussion of Results}

The indicator framework (Table 1) created for assessing the progress of countries in achieving climate and energy targets by 2020 was applied for Baltic States and statistical data was collected for Estonia, Latvia and Lithuania and EU-27 average.

The climate and energy targets for 20-20-20 set for Baltic States were already achieved in 2019 and ear- lier however more important is to analyze what are the main trends not only main indicators set in targets (energy intensity reduction by $20 \%, 20 \%$ share of renewables in final energy and 20\% GHG emission reduction in comparison with year 1990) but also the trends of supporting indicators which might be treated as the drivers of primary indicators.

The main trends of energy efficiency indicators are presented in Figures 1-6.

Figure 1 shows that energy intensity in Baltic States was decreasing all investigated period however it is still twice higher in Estonia and by $40 \%$ higher in Latvia and 30\% higher in Lithuania.

Figure 2 shows that final energy consumption per capita in Estonia was twice higher than in Latvia though it was declining during investigated period. In Latvia and Lithuania final energy consumption per capita was about 25\% lower than EU-27 during all investigated period.

\section{Figure 1}

Development of Primary Energy Intensity in Baltic States and EU-27 Average

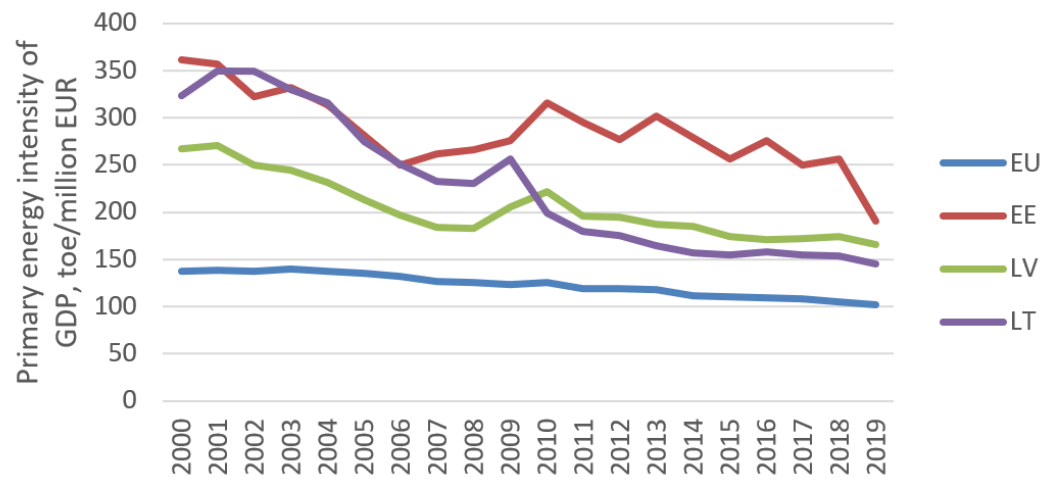




\section{Figure 2}

Development of Final Energy Consumption per Capita in Baltic States and EU-27 Average

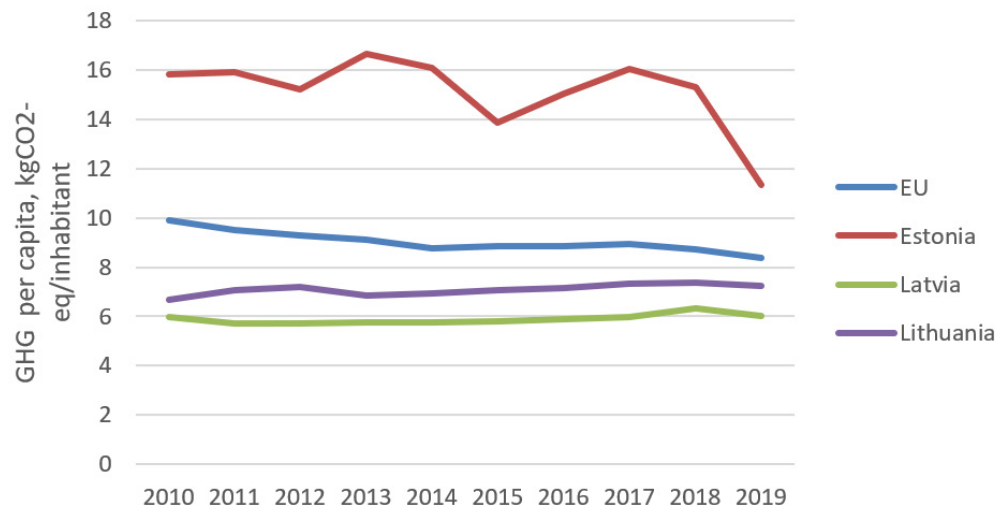

Figure 3 shows that final energy intensity in industry was declining in all Baltic States however it was higher than in EU-27 average during all investigated period. Especially high is energy intensity of industry in Latvia comparing with other Baltic States. Furthermore, though this indicator was declining in Latvia during all investigated period it was still twice higher than EU average in 2019, showing problems in this end use sector and the need to strengthen policies and measures to increase energy efficiency in industry.

\section{Figure 3}

Development of Final Energy Intensity of Industry in Baltic States and EU-27 Average

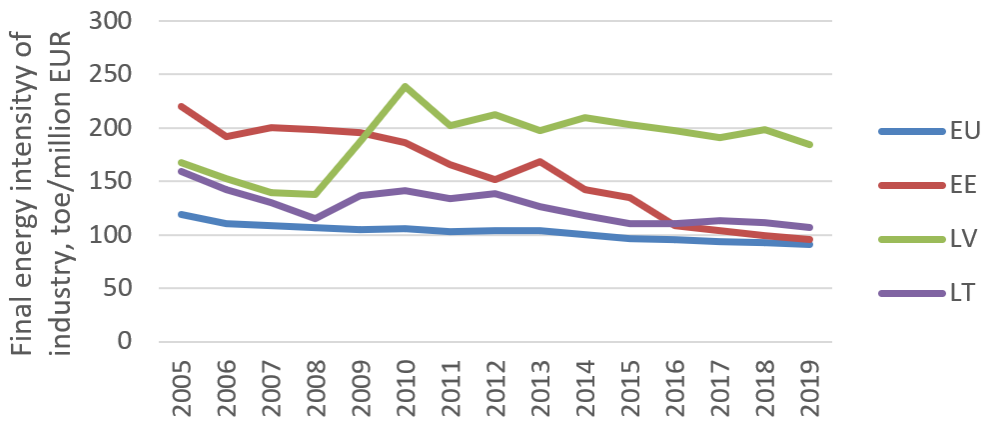


Figure 4 shows that final energy consumption per square meter is the highest in Estonia and it is still increasing. In all Baltic States this indicator was decreasing during investigated period. In 2019 final energy consumption per square meter in residential sector in Lithuania was similar to EU-27 level showing good progress in energy efficiency improvement in residential sector which was mainly achieved due to energy renovation programmes. In Estonia this indicator was almost twice higher than EU-27 level showing problems in this end-use sector and the need of additional policies and measures.

\section{Figure 4}

Development of Final Energy Consumption per Square Meter in Residential Sector of Baltic States and EU-27 Average

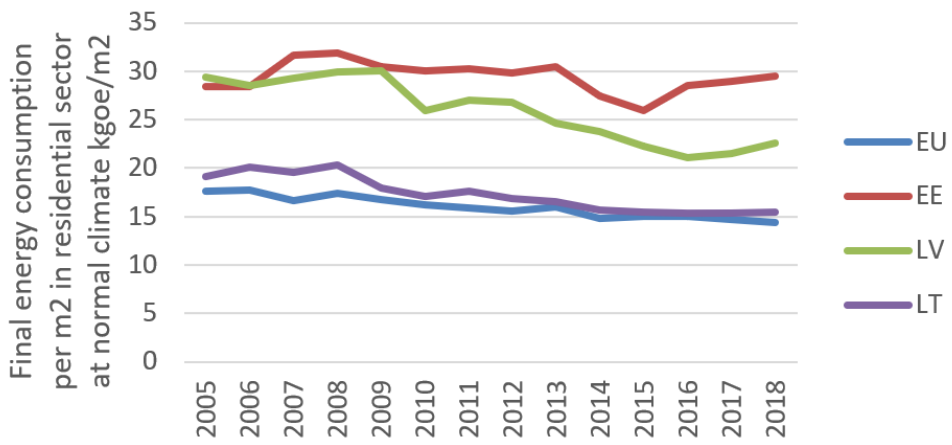

Figure 5 shows that like in case of energy intensity in industry, Baltic states have significantly higher energy intensity of service sector in comparison with EU-27 average. Though during investigated period energy intensity of service sector was declin- ing in all Baltic States in 2019 it was twice higher in Estonia and Latvia comparing with EU-27. This indicates the problem of energy efficiency in this end user sector and the necessity of additional policies and measures.

\section{Figure 5}

Development of Energy Intensity in Service Sector of Baltic States and EU-27 Average

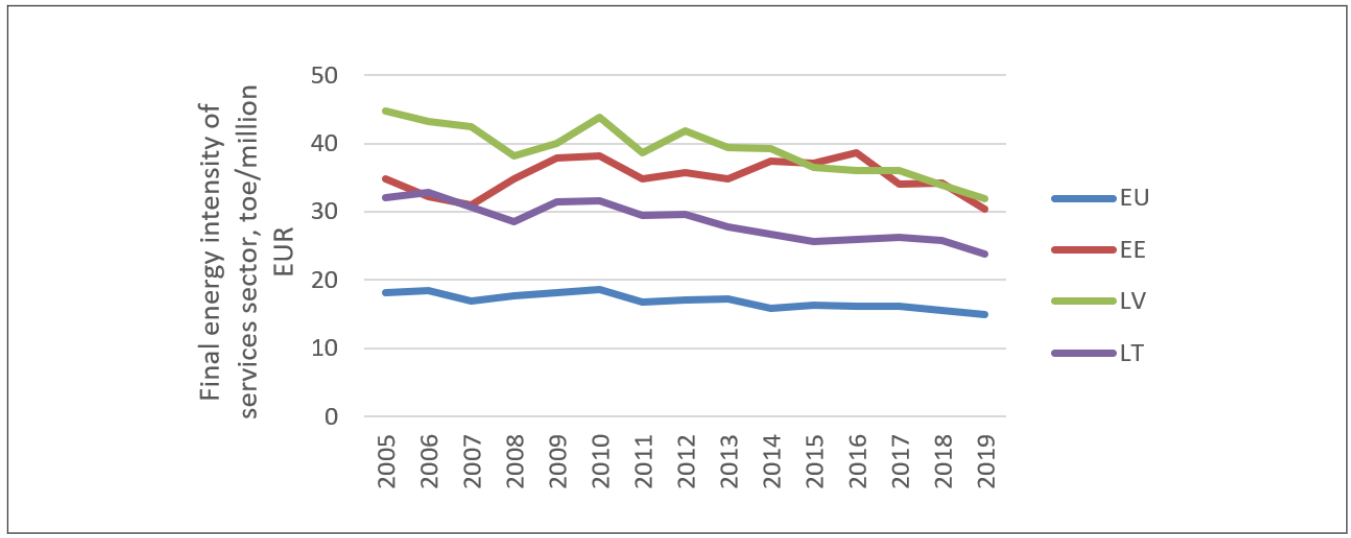


Figure 6 shows that Lithuania distinguishes with very low public transport share, though some trends of increase can be noticed. Latvia has the similar share like EU-27. Estonia had even higher share than EU-27. Lithuania needs to address this problem and promote use of public transport in- stead of private cars. This allows to reduce energy use and achieve GHG emission reduction in transport.

In Figures 7-11 the trends of renewable energy indicators were compared for Baltic States and EU27 average.

\section{Figure 6}

Development of the Share of Public Transport in All Passenger's Transport in Baltic States and EU-27 Average

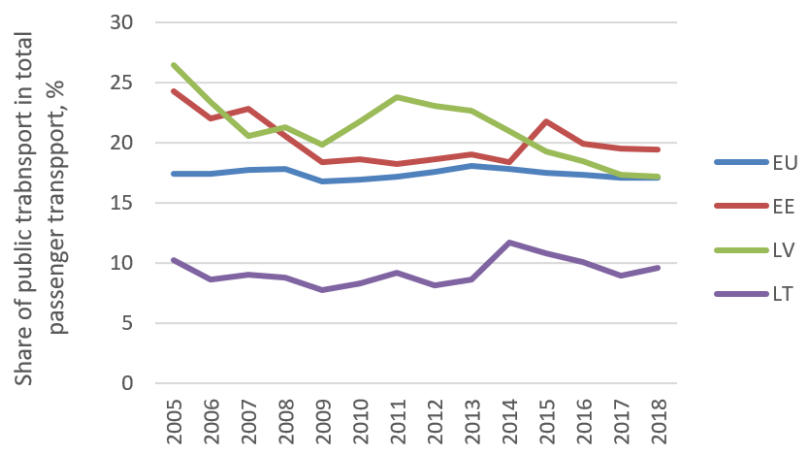

Figure 7 shows that Baltic States have significantly higher share of renewables in final energy consumption comparing to EU-27 and this share was increasing all investigated period. Latvia due to very high share of hydro is leading country among Baltic States and other EU MS.

\section{Figure 7}

Development of the Share of Renewables in Final Energy Consumption in Baltic States and EU-27 Average

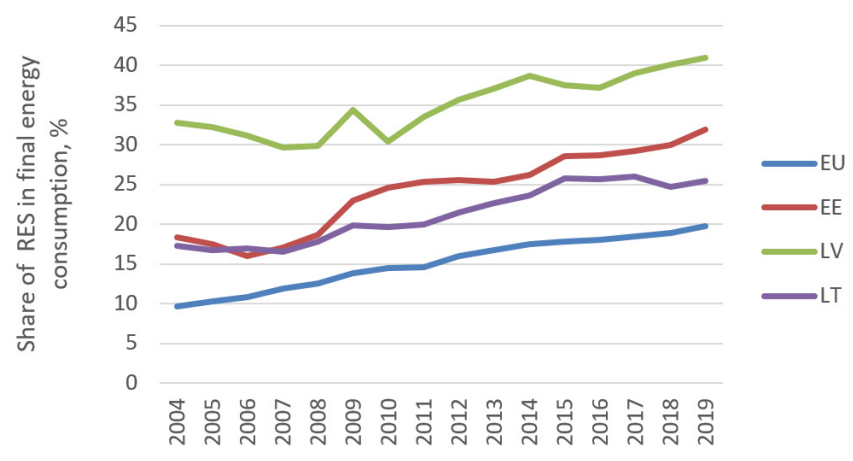


Figure 8 shows that Baltic States are lagging in the use of renewables in transport in comparison with EU-27 though the trend is positive. New policies and measures are necessary in this field.

\section{Figure 8}

Development of the Share of Renewables in Transport in Baltic States and EU-27 Average

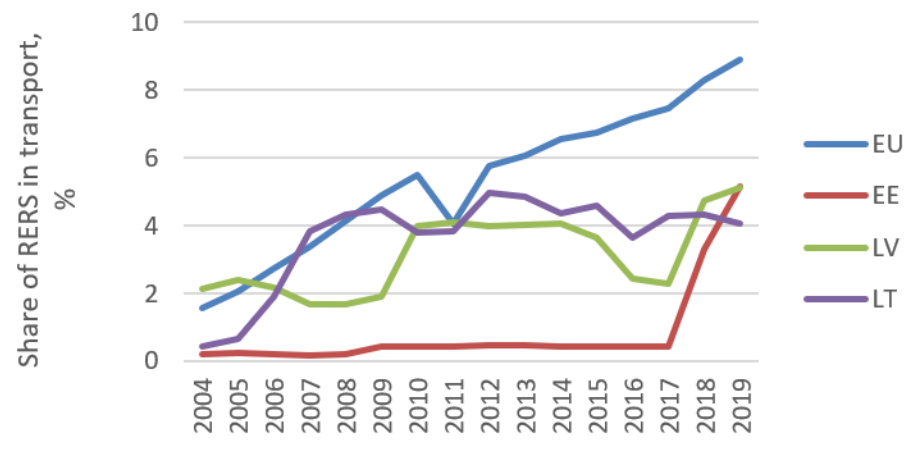

Figure 9 shows that Latvia distinguishes with very high share of RES in electricity generation. Lithuania and Estonia had by $35 \%$ lower share than EU-27 average in 2019. Though the share of renew- ables in electricity generation was increasing in Baltic Sates during investigated period, additional policies and measures are necessary in Lithuania and Estonia.

\section{Figure 9}

Development of the Share of Renewables in Electricity in Baltic States and EU-27 Average

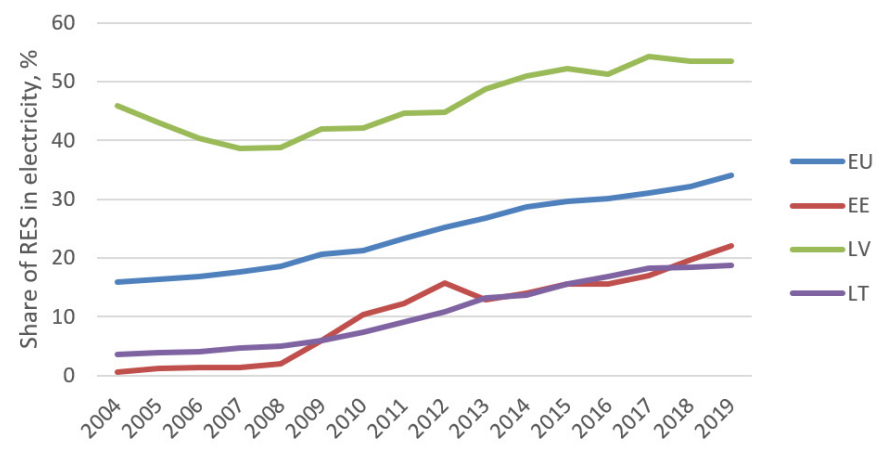


Figure 10 shows that Baltic States distinguished with very high shares of RES in heating and cool- ing in comparison with EU-27 average during all investigated period.

\section{Figure 10}

Development of the Share of Renewables in Heating and Cooling in Baltic States and EU-27 Average

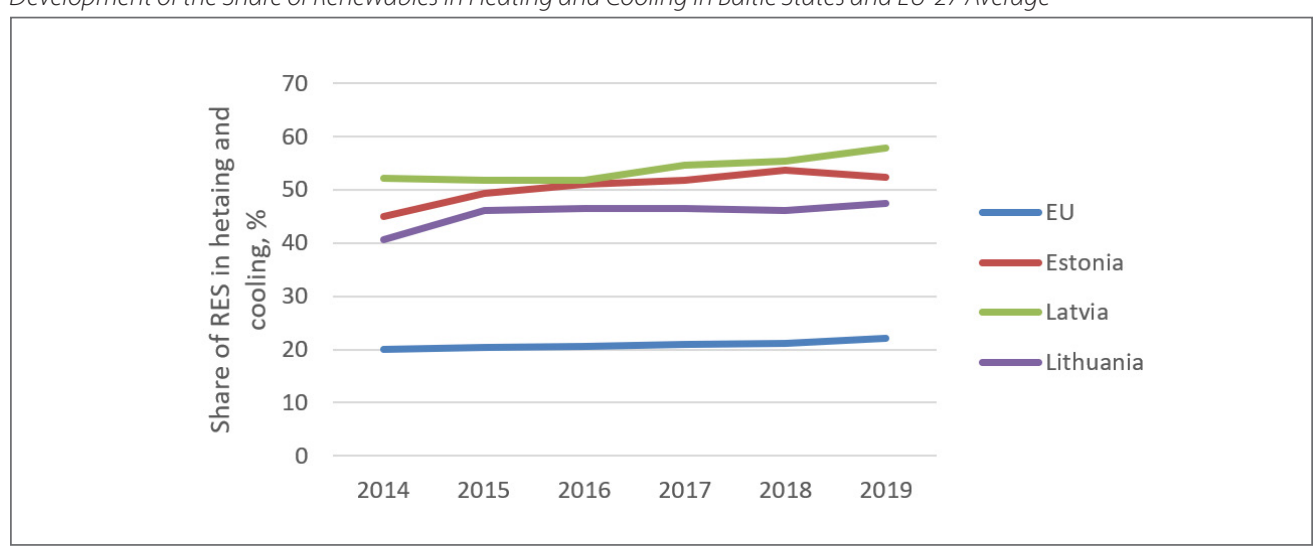

Figure 11 shows that Estonia has achieved the best results in avoidance of fossil fuels due to penetration of renewables among Baltic States.
In Figures 11-16 the trends of GHG emission indicators were compared for Baltic States and EU-27 average.

\section{Figure 11}

Development of the Fossil Fuel Avoidance due to RES in Baltic States and EU-27 Average

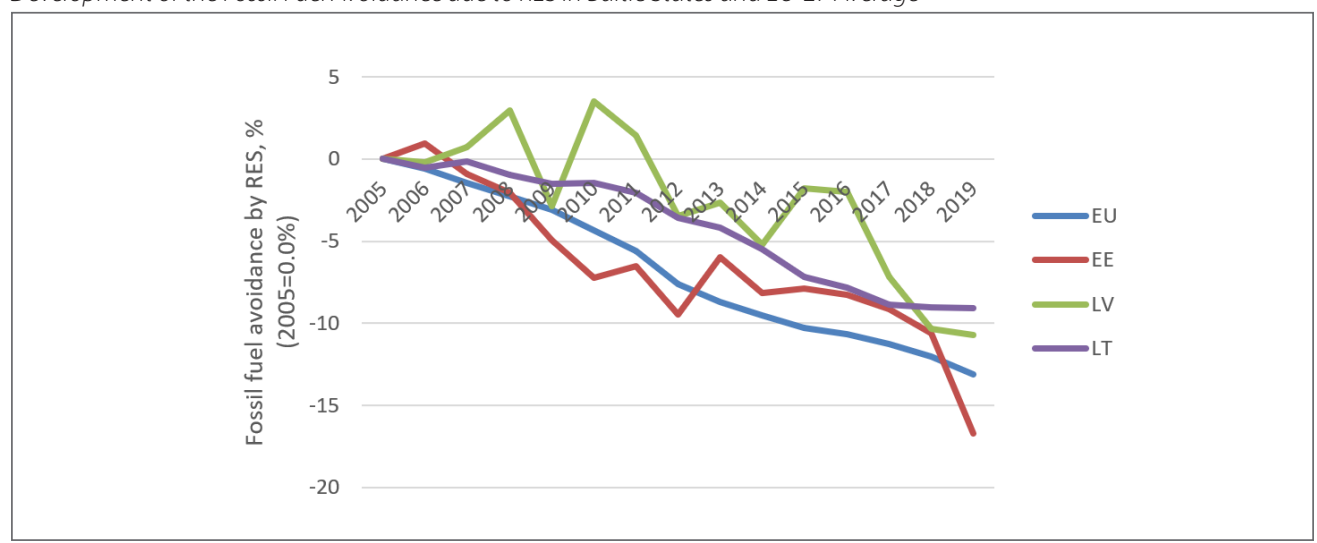


Figure 12 shows that Baltic States have achieved almost $60 \%$ GHG emission reduction in comparison with year 1990. This is higher result as EU-27 because Baltic States had very high GHG emissions in 1990 due to Soviet past linked to very high inefficient energy consumption levels.

\section{Figure 12}

Development of GHG Emission Reduction in Baltic States and EU-27 Average

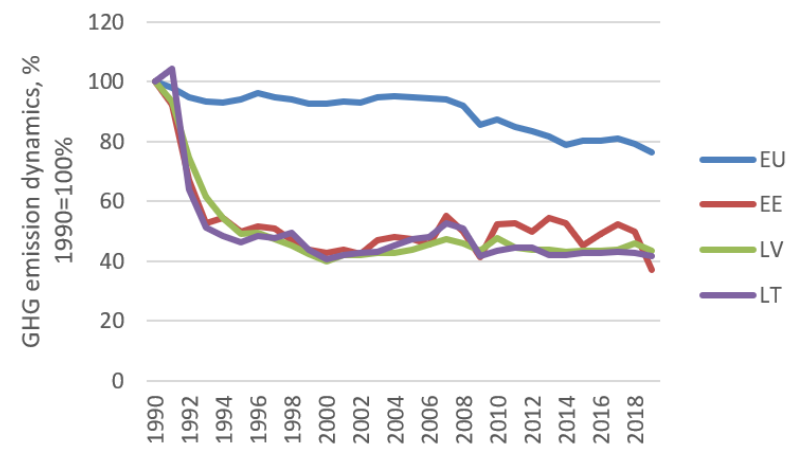

Figure 13 shows that Estonia distinguishes with very high GHG intensity of GDP. This is due to very high GHG emission intensity of energy generation and very high primary energy intensity of GDP. Though GHG intensity of GDP has significantly decreased during investigated period in Estonia, it is still almost twice higher than EU-27 average. Latvia and Lithuania have GHG emission intensity slowly lower than in EU-27. It is necessary to stress that GHG emission intensity of GDP was decreasing during all observed period.

\section{Figure 13}

GHG Emission Intensity in Baltic States and EU-27 Average

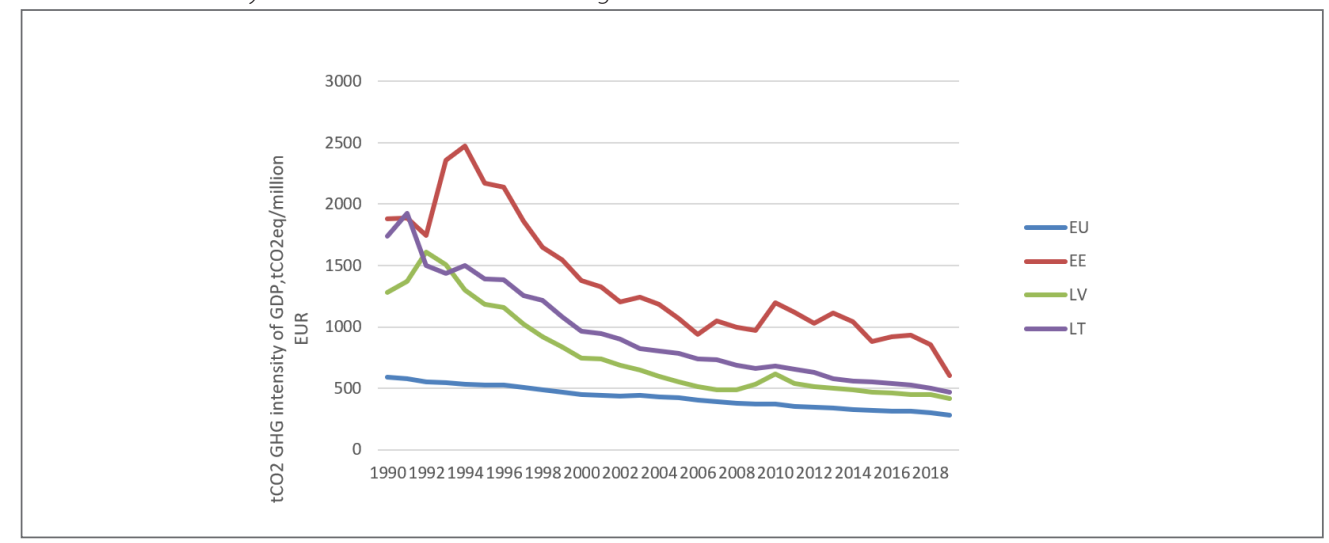


Figure 14 shows that Estonia distinguishes with very high GHG per capita. Though GHG per capita has significantly decreased during investigated pe- riod in Estonia, it is still almost twice higher than in than in Latvia which distinguishes with lowest GHG emissions per capita among investigated countries.

\section{Figure 14}

GHG Emission Per Capita in Baltic States and EU-27 Average

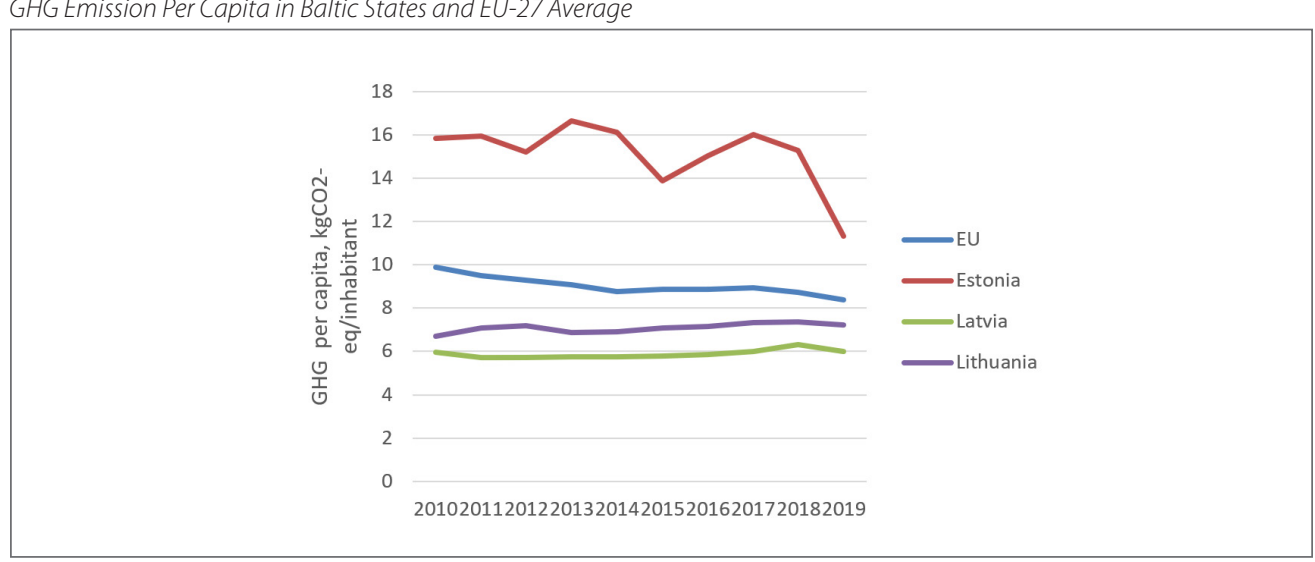

Figure 15 shows that Estonia has twice higher GHG intensity of power and heat generation in comparison with EU-27 and Latvia and Lithuania distinguishes with 1,5-2 times lower GHG intensity of power and heat generation than EU-27 average. This is due to very high share of RES in heating and cooling.

\section{Figure 15}

GHG Emission Per Capita in Baltic States and EU-27 Average

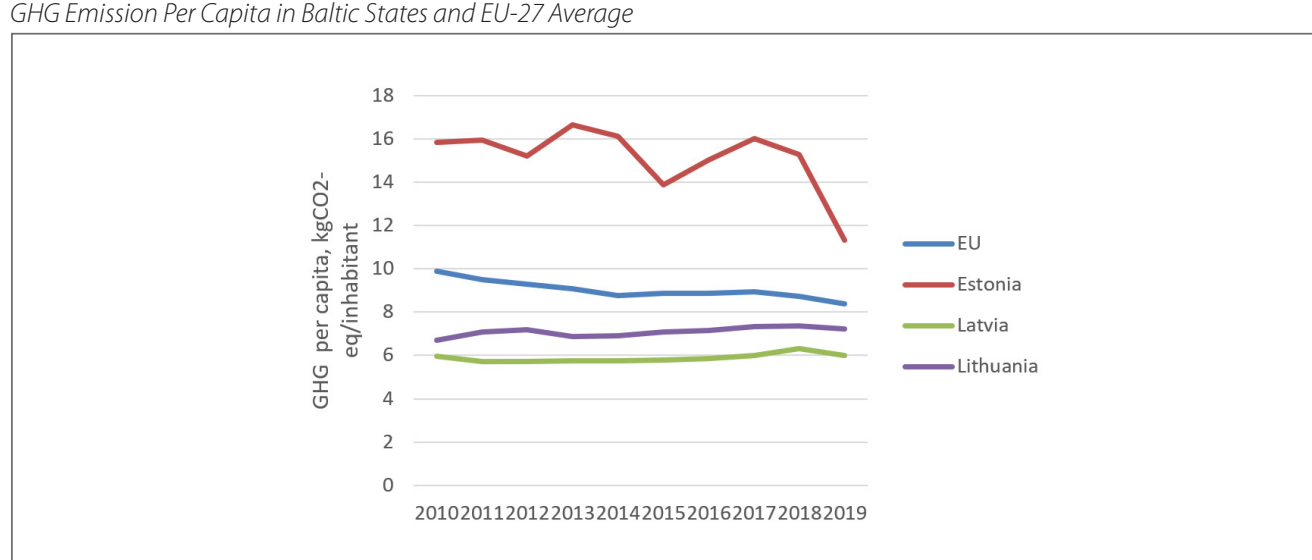


Figure 16 shows that Lithuania achieved highest GHG emission avoidance due to penetration of renewables though according to fossil fuel avoidance by RES, Estonia was the best performing country.
In Table 2 the Baltic States and EU-27 average indicators of implementation of climate and energy targets 20-20-20 in 2019 are provided. The EU27 average data allows to compare Baltic States with the benchmark.

\section{Figure 16}

GHG Emission Avoidance due to RES, \% vs 2005 in Baltic States and EU-27 Average

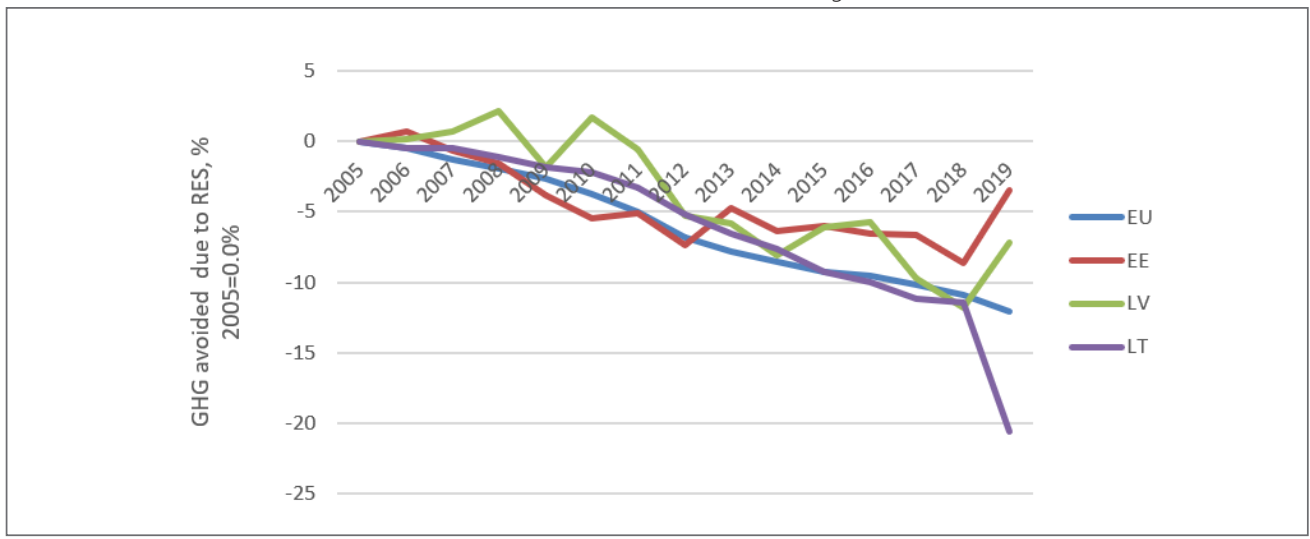

Table 2

Baltic States Indicators of Implementation of Climate and Energy Targets in 2019

\begin{tabular}{|c|c|c|c|c|}
\hline Main indicators & EU-27 & Estonia & Latvia & Lithuania \\
\hline \multicolumn{5}{|l|}{ Energy intensity } \\
\hline Primary energy intensity, toe/Million EUR 2010 prices & 101.80 & 190.05 & 165.44 & 144.96 \\
\hline Final energy consumption per capita, toe/thousand inhabitants & 551.31 & 718.08 & 618.76 & 517.93 \\
\hline Final energy intensity in industry, toe/Million EUR 2010 prices & 90.41 & 95.79 & 184.24 & 106.36 \\
\hline $\begin{array}{l}\text { Final energy consumption per square meter in residential sector, climate cor- } \\
\text { rected, kgoe } / \mathrm{m} 2\end{array}$ & 14.42 & 29.54 & 22.57 & 15.43 \\
\hline Share of collective transport in all passengers' transport, \% & 17.1 & 19.4 & 17.2 & 9.6 \\
\hline Final energy intensity in services sector, toe/Million EUR 2010 prices & 14.42 & 29.54 & 22.57 & 15.43 \\
\hline \multicolumn{5}{|c|}{ Renewable energy sources } \\
\hline Renewable energy share in final energy consumption, $\%$ & 19.72 & 31.89 & 40.98 & 25.46 \\
\hline RES share in transport, \% & 8.90 & 5.15 & 5.11 & 4.05 \\
\hline RES share electricity, \% & 34.08 & 22.00 & 53.42 & 18.79 \\
\hline RES share heating \& cooling, \% & 22.09 & 52.28 & 57.76 & 47.36 \\
\hline Fossil fuels avoidance by RES, \% vs 2005 (2005=0.0\%) & -13.12 & -16.72 & -10.73 & -9.06 \\
\hline \multicolumn{5}{|l|}{ GHG emissions } \\
\hline GHG emissions reductions (base year=1990), \% & 76.34 & 37.19 & 43.45 & 41.76 \\
\hline GHG intensity, t CO2eq /Million EUR 2010 prices & 282.33 & 605.95 & 418.62 & 466.97 \\
\hline GHG per capita, kg CO2-eq/inhabitant & 8.39 & 11.34 & 6.01 & 7.24 \\
\hline GHG intensity of power \& heat generation, $\mathrm{CO} 2 /$ toe & 3.14 & 7.61 & 1.53 & 1.034 \\
\hline GHG emissions avoided due to RES, \% vs $2005(2005=0.0 \%)$ & -12.04 & -3.46 & -7.20 & -20.64 \\
\hline
\end{tabular}


Table 2 provides results of the main climate and energy indicators for Baltic States and EU-27 average in 2019 (newest available data form EUROSTAT).

Furthermore, information available in Table 2 allows to rank Baltic States according position in achievement of desirable targets for energy efficiency improvement and increase of use of renewables and GHG emission reduction.

In Table 3 the ranking of Baltic States based on the achievement in the main energy intensity, renewable energy and GHG emission reduction indicators and overall ranking on progress in implementing 2020 climate and energy targets in 2019 is provided.

Though the main climate and energy targets are expressed by reduction of energy intensity by $20 \%$, reduction of GHG emissions by $20 \%$ and $20 \%$ of the share of renewables in final energy consumption by 2020, the other supplement indicators provided in the table and included in the indicator's framework allows to understand better what are the main drivers of achieved progress. Primary energy intensity reduction is achieved by decreasing energy intensities in industry, services and energy consumption per square meter in residential sector as well as due to increase of the share of public transport in all passenger's transport. Final energy consumption per capita also allows to understand the overall energy saving trends in the country in case of decline of this indicator.

Additional to the share of renewable in final energy consumption indicators such as the share of renewable energy in transport, heating and cooling and electricity generation, fossil fuel avoidance due

\section{Table 3}

Ranking Baltic States Based on Progress towards Climate and Energy Targets

\begin{tabular}{|c|c|c|c|c|}
\hline Main indicators & Target & Estonia & Latvia & Lithuania \\
\hline \multicolumn{5}{|l|}{ Energy intensity } \\
\hline Primary energy intensity, toe/Million EUR 2010 prices & Min & 3 & 2 & 1 \\
\hline Final energy consumption per capita, toe/thousand inhabitants & Min & 3 & 2 & 1 \\
\hline Final energy intensity in industry, toe/Million EUR 2010 prices & Min & 1 & 3 & 2 \\
\hline $\begin{array}{l}\text { Final energy consumption per square meter in residential sector, climate cor- } \\
\text { rected, kgoe/m2 }\end{array}$ & Min & 3 & 2 & 1 \\
\hline Share of collective transport in all passengers' transport, \% & $\operatorname{Max}$ & 1 & 2 & 3 \\
\hline Final energy intensity in services sector, toe/Million EUR 2010 prices & Min & 3 & 2 & 1 \\
\hline Total & & 14 & 13 & 9 \\
\hline \multicolumn{5}{|c|}{ Renewable energy sources } \\
\hline Renewable energy share in final energy consumption, \% & $\operatorname{Max}$ & 2 & 1 & 3 \\
\hline RES share in transport, \% & $\operatorname{Max}$ & 1 & 2 & 3 \\
\hline RES share electricity, \% & Max & 2 & 1 & 3 \\
\hline RES share heating \& cooling, $\%$ & Max & 2 & 1 & 3 \\
\hline Fossil fuels avoidance by RES, \% vs 2005 (2005=0.0\%) & $\operatorname{Max}$ & 1 & 2 & 3 \\
\hline Total & & 8 & 7 & 15 \\
\hline \multicolumn{5}{|l|}{ GHG emissions } \\
\hline GHG emissions reductions (base year=1990), \% & Min & 1 & 3 & 2 \\
\hline GHG intensity, t CO2eq / Million EUR 2010 prices & Min & 3 & 1 & 2 \\
\hline GHG per capita, kg CO2-eq/inhabitant & Min & 3 & 1 & 2 \\
\hline GHG intensity of power \& heat generation, $\mathrm{CO} 2 /$ toe & Min & 3 & 2 & 1 \\
\hline GHG emissions avoided due to RES, \% vs 2005 (2005=0.0\%) & $\operatorname{Max}$ & 3 & 2 & 1 \\
\hline Total & & 13 & 9 & 8 \\
\hline Final Rank & & 35 & 29 & 32 \\
\hline
\end{tabular}


to renewables also allow to understand which sectors are the main drivers of progress in renewable energy penetration in the country.

As a number of factors influence the quantities of GHG emissions including economic activity, population, consumption patterns, technologies etc., additional GHG emission reduction indicators, like GHG intensity, GHG emissions per capita, GHG intensity of power \& heat generation and GHG emission avoidance due to penetration of renewables also provides important additional information about the main drivers of GHG emission reduction. GHG intensity of economy shows the GHG emission per GDP is linked to energy intensity of economy and carbon intensity of energy consumed.

Based on the ranking of Baltic States according the indicators presented in Table 3, allows to develop policy recommendations and to strengthen policies in specific area.

Countries that have achieved good results in energy efficiency improvement like Lithuania can be lagging in achieving renewable energy penetration targets, though in GHG emission reduction the moderate results are achieved. Energy efficiency improvement and penetration of renewables are the main ways to achieve GHG emission reduction in energy sector. Therefore, based on information provided by indicators set the energy and climate change policy recommendations can be developed for countries.

As one can see in information provided in Table 3 , Latvia has the best ranking based on progress towards climate and energy targets for 2020 in 2019. The best position in total ranking was obtained for Latvia due to its moderate position according implementation of energy efficiency, renewables and GHG emission targets.

Estonia is lowest performing country according overall assessment as it is ranked as the worst performing according to energy efficiency and GHG emission reduction targets.

Lithuania is distinguishing with the best performance according to energy efficiency and lowest performance according renewable energy targets. Furthermore, the final ranking of Lithuania puts country in the middle position among Baltic States.

\section{Conclusions and Policy Implications}

Comparative assessment of Baltic States in achievement of climate and energy targets 20-20-20 indicated that Latvia has the best ranking based on progress towards overall climate and energy targets for 2020 in 2019. Estonia was found as lowest performing country according overall assessment due to worst performance according to energy efficiency and GHG emission reduction targets. Lithuania is showing the best performance according to energy efficiency and lowest performance according to renewable energy targets and is in the middle position in overall ranking.

The main policy recommendations are to put more emphasis on energy efficiency by fostering integration of energy efficiency measures in all end user sectors by reducing regulatory and pricing barriers, and large-scale programmes for renovation should be priority, especially in Estonia having worst indicators of energy efficiency, including final energy consumption per square meter in residential sector.

For Lithuania more emphasis is necessary for promotion of renewables as country has the worst indicators of renewables. It is important to ensure necessary investment in order to keep all technology options open for achieving zero carbon energy transition in Lithuania and other countries.

Latvia has the highest energy intensity in industry, therefore energy efficiency improvements in industry should be priority for the country.

For implementation of 2030 framework new policies to scale up energy action towards climate neutrality are necessary for all Baltic States while ensuring energy security and energy affordability.

\section{Limitation and Future Research}

Speaking about the limitation of our research, several issues come to mind: the analysis performed in this paper is based on comparative assessment of selected indicators between neighboring countries. Comparative assessment between countries allows by comparing indicators of countries to look deeper in their energy and climate policies and share good practices. Future research is necessary in order to analyze and compare energy and climate policies in Baltic States. The ranking of policies can also be 
performed by linking them with specific climate and energy indicators. More advanced and robust multi-criteria decision adding tools will be applied for ranking of countries.

\section{References}

European Commission (2020). The 2020 Climate and Energy Package, Climate Action, online available at: http://ec.europa.eu/clima/policies/package/ index_en.htm(link is external)

European Commission (2020). 2030 framework for climate and energy policies, Climate Action, online available at: http://ec.europa.eu/clima/ policies/2030/index_en.htm

European Commission (2020). Eurostat. https:// ec.europa.eu/eurostat.

Aklin, M., Cheng, C. Y., \& Urpelainen, J. (2018). Social acceptance of new energy technology in developing countries: A framing experiment in rural India. Energy Policy, 113, 466-477

Al-Marri, W., Al-Habaibeh, A., \& Watkins, M. (2018). An investigation into domestic energy consumption behaviour and public awareness of renewable energy in Qatar. Sustainable Cities and Society, 41, 639-646. https://doi.org/10.1016/j. scs.2018.06.024

Aslanturk, O., \& Kiprizli, G. (2020). The role of renewable energy in ensuring energy security of supply and reducing energy-related import. International Journal of Energy Economics and Policy, 10(2), 354-359.

Batinge, B., Musango, J. K., \& Brent, A. C. (2019). Sustainable energy transition framework for unmet electricity markets. Energy Policy, 129, 1090-1099. https://doi.org/10.1016/j. enpol.2019.03.016

Bergek, A., \& Mignon, I. (2017). Motives to adopt renewable electricity technologies: Evidence from Sweden. Energy Policy, 106, 547-559. https://doi. org/10.1016/j.enpol.2017.04.016

Brodny, J., \& Tutak, M. (2020). Analyzing similarities between the European Union countries in terms of the structure and volume of energy production from renewable energy sources. Energies, 13(4), 913. https://doi.org/10.3390/en13040913

Clausen, L. T., \& Rudolph, D. (2020). Renewable energy for sustainable rural development: Synergies and mismatches. Energy Policy, 138, 111289. https://doi.org/10.1016/j. enpol.2020.111289

Dell'Anna, F. (2020). Green jobs and energy efficiency as strategies for economic growth and the reduction of environmental impacts. Energy Policy, 112031. https://doi.org/10.1016/j. enpol.2020.112031

Elavarasan, R. M., Afridhis, S., Vijayaraghavan, R. R., Subramaniam, U., \& Nurunnabi, M. (2020). SWOT analysis: A framework for comprehensive evaluation of drivers and barriers for renewable energy development in significant countries. Energy Reports, 6, 1838-1864. https://doi. org/10.1016/j.egyr.2020.07.007

Gielen, D., Boshell, F., Saygin, D., Bazilian, M. D., Wagner, N., \& Gorini, R. (2019). The role of renewable energy in the global energy transformation. Energy Strategy Reviews, 24, 3850. https://doi.org/10.1016/j.esr.2019.01.006

Gralla, F., Abson, D. J., Møller, A. P., Lang, D. J., \& von Wehrden, H. (2017). Energy transitions and national development indicators: A global review of nuclear energy production. Renewable and Sustainable Energy Reviews, 70, 1251-1265. https://doi.org/10.1016/j.rser.2016.12.026

Liobikienè, G., \& Butkus, M. (2017). The European Union possibilities to achieve targets of Europe 2020 and Paris agreement climate policy. Renewable Energy, 106, 298-309. https://doi. org/10.1016/j.renene.2017.01.036

Lu, J., Ren, L., Yao, S., Rong, D., Skare, M., \& Streimikis J. (2020). Renewable energy barriers and coping strategies: Evidence from the Baltic States. Sustainable Development, 28(1), 352-367. https://doi.org/10.1002/sd.2030

Nathaniel, S., \& Khan, S. A. R. (2020). The nexus between urbanization, renewable energy, trade, and ecological footprint in ASEAN countries. Journal of Cleaner Production, 272, 122709. https://doi.org/10.1016/j.jclepro.2020.122709

Neofytou, H., Nikas, A., \& Doukas, H. (2020). Sustainable energy transition readiness: A multicriteria assessment index. Renewable and Sustainable Energy Reviews, 131, 109988. https:// doi.org/10.1016/j.rser.2020.109988

Singh, H. V., Bocca, R., Gomez, P., Dahlke, S., \& Bazilian, M. (2019). The energy transitions index: an analytic framework for understanding the evolving global energy system. Energy Strategy Reviews, 26, 100382. https://doi.org/10.1016/j. esr.2019.100382

Tagliapietra, S., Zachmann, G., Edenhofer, O., Glachant, J. M., Linares, P., \& Loeschel, A. (2019). The European union energy transition: Key priorities for the next five years. Energy 
Policy, 132, 950-954. https://doi.org/10.1016/j. enpol.2019.06.060

Yan, Q., Qin, G., Zhang, M., Li, W., \& Chen, L. (2020a). Research on power customer comprehensive evaluation and service strategy based on fuzzy theory and TOPSIS in opening electricity market. Transformations in Business \& Economics, 19(2), 199-219.

Yan, Q., Zhang, W., Yuan, J., Ai, Y., \& Lu, G. (2020b), The economy of power generation technologies in China: A review. Transformations in Business \& Economics, 19(1), 95-111.

Yu, L., Xue, B., Stückrad, S., Heiko, T., \& Cai, G. (2020). Indicators for energy transition targets in China and Germany: A text analysis. Ecological Indicators, 111, 6012, doi.org/10.1016/j. ecolind.2019.10601 